\title{
ELECTROCHEMICAL PROPERTIES OF AQUEOUS SOLUTIONS OF SODIUM
} \section{AMINOMETHANESULFONATES}

R. E. Khoma ${ }^{1,2^{*}}$, A. A.-A. Ennan ${ }^{1}$, A. N. Chebotarev ${ }^{2}$, S. V. Vodzinskii ${ }^{1,2}$, R. M. Dlubovskii ${ }^{1}$, S. V. Toporov ${ }^{2}$

${ }^{1}$ Physico-Chemical Institute of Environment and Human Protection, Preobrazhenskaya str., 3, Odessa 65082, Ukraine

${ }^{2}$ Odessa I.I. Mechnikov National University, Dvoryankaya str., 2, Odessa 65082, Ukraine *e-mail:rek@onu.edu.ua

The $\mathrm{pH}$ and conductometric study of the electrochemical properties of aqueous solutions $\left(1 \cdot 10^{-4} \div 9 \cdot 10^{-3} \mathrm{M}\right) \mathrm{YNHCH}_{2} \mathrm{SO}_{3} \mathrm{Na}\left(\mathrm{Y}=\mathrm{H}, \mathrm{CH}_{3}, \mathrm{HOCH}_{2} \mathrm{CH}_{2},\left(\mathrm{CH}_{3}\right)_{3} \mathrm{C}\right.$ and $\left.\mathrm{C}_{6} \mathrm{H}_{5} \mathrm{CH}_{2}\right)$ was carried out. The values of the limiting electrical conductivity were calculated by extrapolation according to Shidlovsky. The activation parameters of the electrical conductivity of the systems "sodium aminomethanesulfonate $-\mathrm{H}_{2} \mathrm{O}$ " at 293-313 K were obtained.

Key words: aminomethanesulfonic acids, aqueous solutions, hydrolysis, conductivity.

INTRODUCTION. The theoretical interest in aminomethanesulfonic acid and its $\mathrm{N}$-alkylated derivatives is be explained by their specific physicochemical properties and a wide spectrum of biological activity [1-5]. Under physiological conditions $(\mathrm{pH}=6.8-7.8)$, the degree of dissociation of the sulfo group, in contrast to $a$-aminocarboxylic acids, is $100 \%$, and the $\mathrm{p} K_{a}$ values of the amino group are in the range of physiological $\mathrm{pH}$ values [6-9]. The sulfo group can act as an anionic fragment and a hydrogen bond acceptor when interacting with a potential biological target [10].

Solubility and permeability are two biopharmaceutical parameters responsible for effective bioavailability and good correlation between in vitro and in vivo studies [11]. The improvment of solubility and dissolution rate, as well as bioavailability of amino acids, continues to be a challenge for pharmaceutical technologists. The hydrotropic action of sulfonates and amino acids is considered as one of the important methods of solubilization [12, 13]. Conductometric studies of aminomethanesulfonates at a definite and infinite dilution in a solvent system provide valuable information about ion-ion (complexation, association) and ion-solvent (solvation) interactions.

Therefore, the determination of the temperature and concentration dependences of the molar electrical conductivity of aqueous solutions of sodium aminomethanesulfonates and monoethanolammonium is, of course, an actual task. To determine the factors affecting the electrical conductivity of aqueous solutions of sodium aminomethanesulfonates, 
a $\mathrm{pH}$ and conductometric study of their behavior was carried out in the temperature range of $293-313 \mathrm{~K}$.

EXPERIMENTAL PART. The studies used AMSA, its N-methyl (MeAMSA), N-(2hydroxyethyl) (HEAMSA), N-tert-butyl (t-BuAMSA) and N-benzyl (BzAMSA) derivatives synthesized according to original methods [3, 14]. Aqueous solutions of sodium salts $\mathrm{YNHCH}_{2} \mathrm{SO}_{3} \mathrm{Na}(\mathrm{Y}=\mathrm{H}(\mathbf{A M S N a})$, $\mathrm{CH}_{3}$ (MeAMSNa), $\mathrm{HOCH}_{2} \mathrm{CH}_{2}$ (HEAMSNa), $\left(\mathrm{CH}_{3}\right)_{3} \mathrm{C} \quad(\boldsymbol{t}$-BuAMSNa $)$ and $\mathrm{C}_{6} \mathrm{H}_{5} \mathrm{CH}_{2}$ (BzAMSNa)) were prepared by $\mathrm{NaOH}$ reacting with the corresponding acids in equimolar amounts.

Potentiometric measurements were carried out using a universal ЭB-74 ionomer and a $\mathrm{pH}$-meter of the $\mathrm{pH}-150 \mathrm{M}$ type. The $\mathrm{pH}$ measurement accuracy was \pm 0.05 units (ЭB-74) and \pm 0.02 units ( $\mathrm{pH}-150 \mathrm{M})$, and for the redox potential $\pm 1 \mathrm{mV}$ (ЭB-74). Conductometric measurements were performed on an Expert-002 conductometer (the relative error was $\leq 0.5 \%$ ).

Electrochemical properties of aqueous solutions of sodium aminomethanesulfonates

Fig. 1-5 show the results of $\mathrm{pH}$ and conductometric studies of aqueous solutions $\left(1 \cdot 10^{-4}\right.$ $\left.\div 1 \cdot 10^{-2} \mathrm{M}\right)$ AMSNa, MeAMSNa, HEAMSNa, t-BuAMSNa and BzAMSNa in the temperature range $293 \div 313 \mathrm{~K}$. Judging by the results of conductometric study of the systems AMSNa $\mathrm{H}_{2} \mathrm{O}$ (Fig. $1 b$ ) and YAMSNa $-\mathrm{H}_{2} \mathrm{O}$ (Fig. $2 b-$ $5 b)$, an increase in temperature from 293 to $313 \mathrm{~K}$ is accompanied by an increase in the electrical conductivity of the systems (similar to aqueous solutions of AMSA [15], YAMSA [16] and glycine [11]) due to an increase in the degree of dissociation of electrolytes and (or) the mobility of the resulting ions. In this case, for all the systems under study, acidic properties decrease with an increase in temperature from 293 to $308 \mathrm{~K}$ (Fig. $1 a-5 a$ ).

Aminosulfonic acids, like amino-carboxylic acids, belong to the class of organic ampholytes and in solution can be in several ionic forms. The qualitative and quantitative composition of amino acid forms depends on the type of amino acid and the $\mathrm{pH}$ of the solution $[6,10,11,15]$.
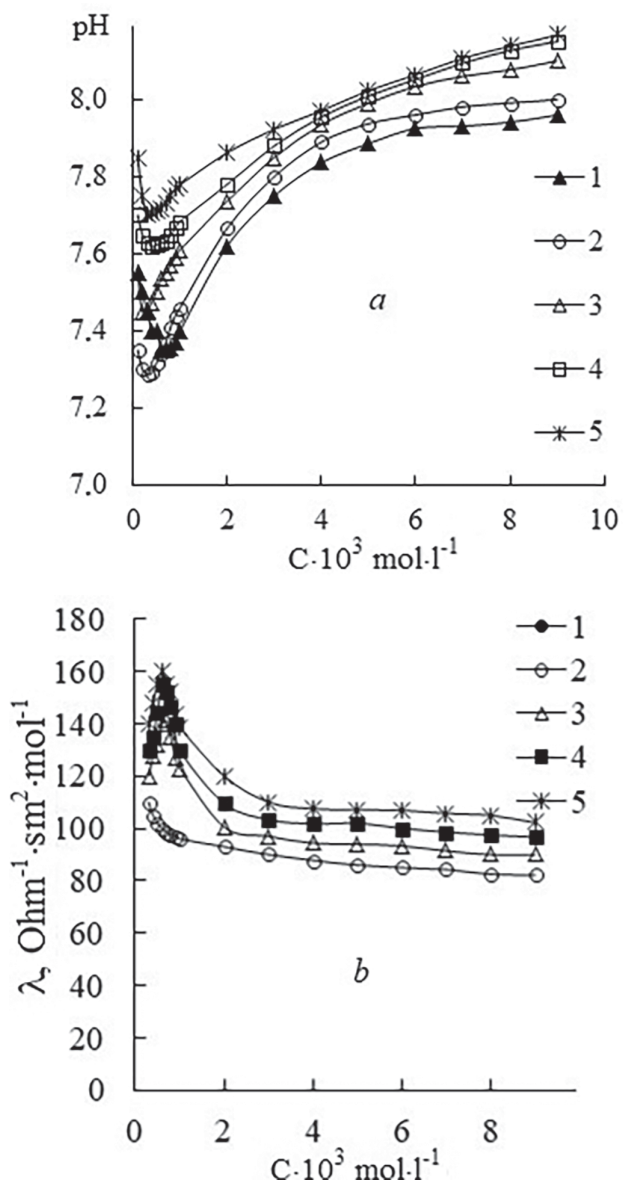

Fig. 1. $\mathrm{pH}(a)$ and molar conductivity $(b)$ of aqueous solutions of AMSNa. T (K): 293-1; 298-2; $303-3 ; 308-4 ; 313-5$.

Even in the simplest case of an aqueous solution of an individual amino acid, a complex mixture is formed, consisting of zwitter- 
ions, amino acid cations and anions, protons, and hydroxyl anions. The mutual influence of all components of the system on each other determines the complexity in the study of the electrochemical behavior of solutions of amino acids and their salts.
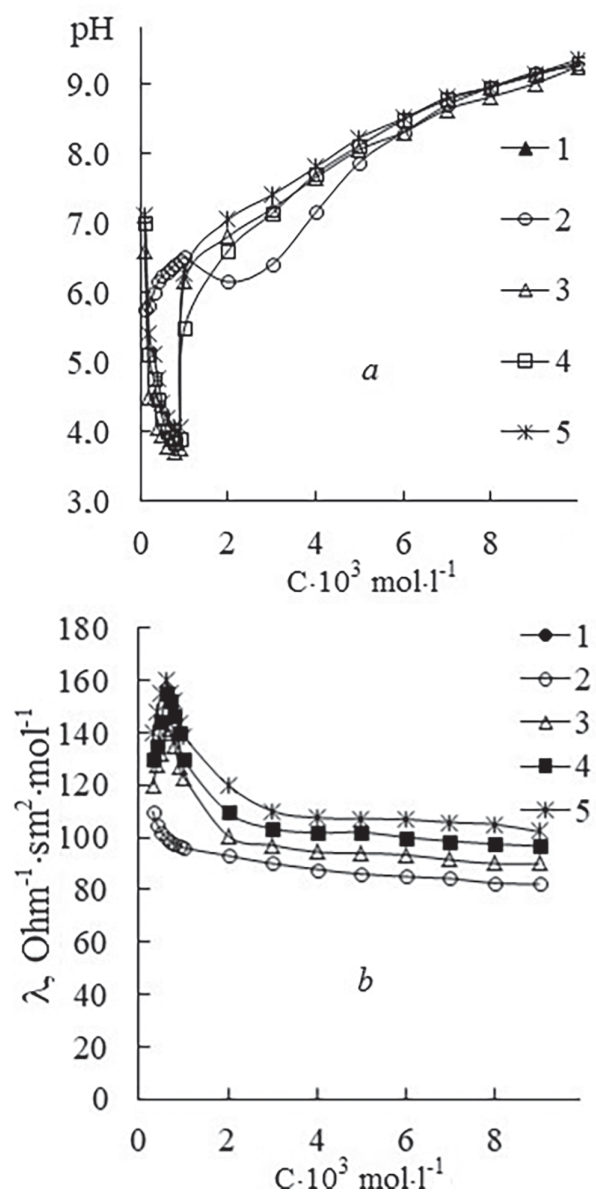

Fig. 2. $\mathrm{pH}(a)$ and molar conductivity (b) of aqueous solutions of MeAMSNa. T (K): 293-1; $298-2$; 303-3; 308-4; 313-5.

In aqueous solutions of YAMSNa $\mathrm{pH}>7.0$ is due to hydrolysis of aminomethanesulfonate ions (reaction 1) with the formation of zwitterions:

$$
\begin{aligned}
& \mathrm{YNHCH}_{2} \mathrm{SO}_{3}^{-}+\mathrm{H}_{2} \mathrm{O} \underset{\leftarrow}{\rightleftarrows} \\
& \stackrel{\mathrm{YN} \mathrm{H}}{\leftarrow} \mathrm{CH}_{2} \mathrm{SO}_{3}^{-}+\mathrm{OH}^{-} \text {, } \\
& K_{\mathrm{h}}=\frac{\left[\mathrm{Y}^{+} \mathrm{H}_{2} \mathrm{CH}_{2} \mathrm{SO}_{2} \mathrm{O}^{-}\right] \cdot\left[\mathrm{OH}^{-}\right]}{\left[\mathrm{YNHCH}_{2} \mathrm{SO}_{2} \mathrm{O}^{-}\right]} \text {. }
\end{aligned}
$$
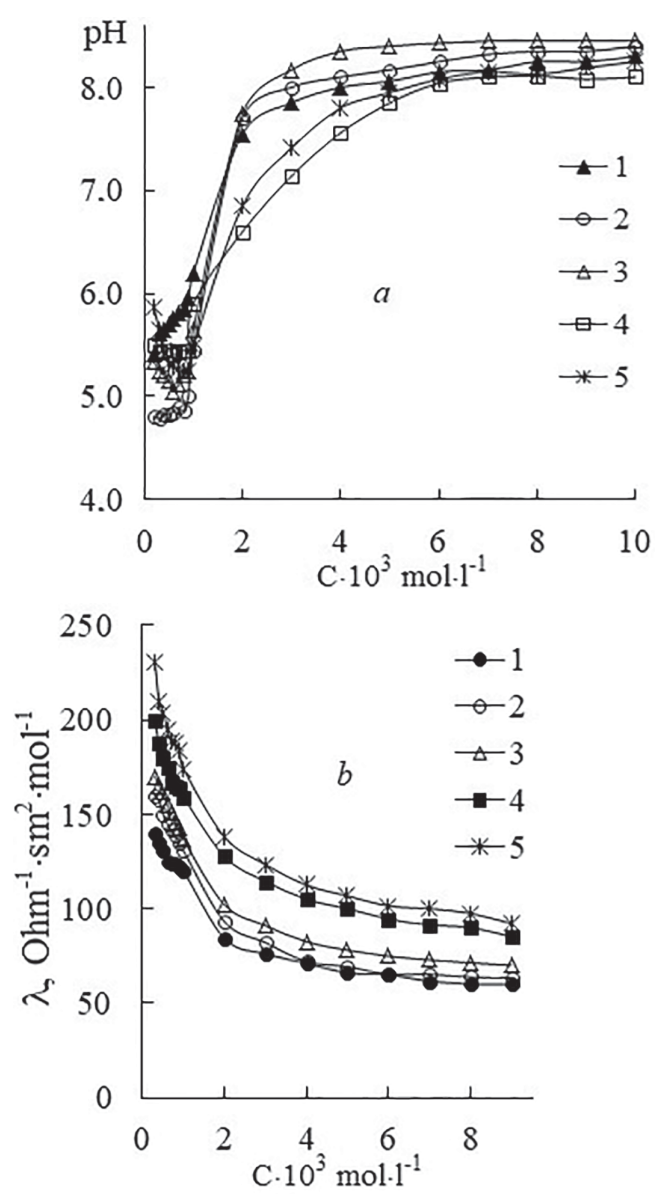

Fig. 3. $\mathrm{pH}(a)$ and molar conductivity $(b)$ of aqueous solutions of HeAMSNa. T (K): 293-1; $298-2 ; 303-3 ; 308-4 ; 313-5$.

With equations (1), (3), we have a system of equations that take into account the law of effective masses (2), material balance according to YAMSA (4) and the condition of electroneutrality (5). 


$$
\begin{gathered}
\mathrm{H}_{2} \mathrm{O} \underset{\leftarrow}{\leftarrow} \mathrm{H}^{+}+\mathrm{OH}^{-} \\
\mathrm{Q}_{\text {YAMSA }}= \\
=\left[\mathrm{Y}_{2}^{+} \mathrm{H}_{2} \mathrm{CH}_{2} \mathrm{SO}_{3}^{-}\right]+\left[\mathrm{YNHCH}_{2} \mathrm{SO}_{3}^{-}\right] \\
{\left[\mathrm{YNHCH}_{2} \mathrm{SO}_{3}^{-}\right]+\left[\mathrm{OH}^{-}\right]=} \\
=\left[\mathrm{H}^{+}\right]+\left[\mathrm{Na}^{+}\right]
\end{gathered}
$$
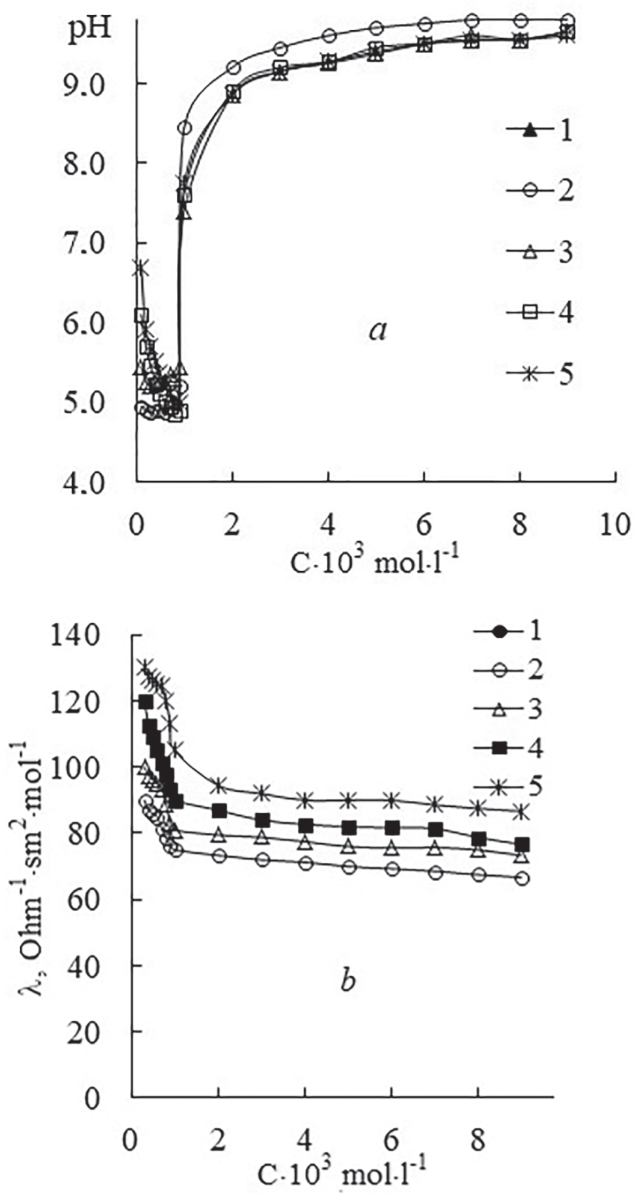

Fig. 4. $\mathrm{pH}(a)$ and molar conductivity $(b)$ of aqueous solutions of $t$-BuAMSNa. T (K): 293-1; $298-2 ; 303-3 ; 308-4 ; 313-5$.

$\mathrm{N}$-alkylation of aminomethanesulfonate anions promotes hydrolytic decomposi- tion by reaction (6) [17]. At $\mathrm{pH}<7.0$, in (3) aqueous solutions of $\mathrm{YAMSNa}\left(\mathrm{Y}-\mathrm{CH}_{3}\right.$, $\mathrm{HOCH}_{2} \mathrm{CH}_{2},\left(\mathrm{CH}_{3}\right)_{3} \mathrm{C}$ and $\left.\mathrm{C}_{6} \mathrm{H}_{5} \mathrm{CH}_{2}\right)$, unlike AMSNa, hydrolytic decomposition of (4) N-alkylaminomethanesulfonate ions occurs with the formation of alkylaminomethanol and hydrosulfite ions:

$$
\begin{aligned}
\mathrm{YNHCH}_{2} \mathrm{SO}_{3}^{-} & +\mathrm{H}_{2} \mathrm{O} \underset{\leftarrow}{\rightarrow} \\
& \leftarrow \mathrm{YNHCH}_{2} \mathrm{OH}+\mathrm{HSO}_{3}^{-} .
\end{aligned}
$$
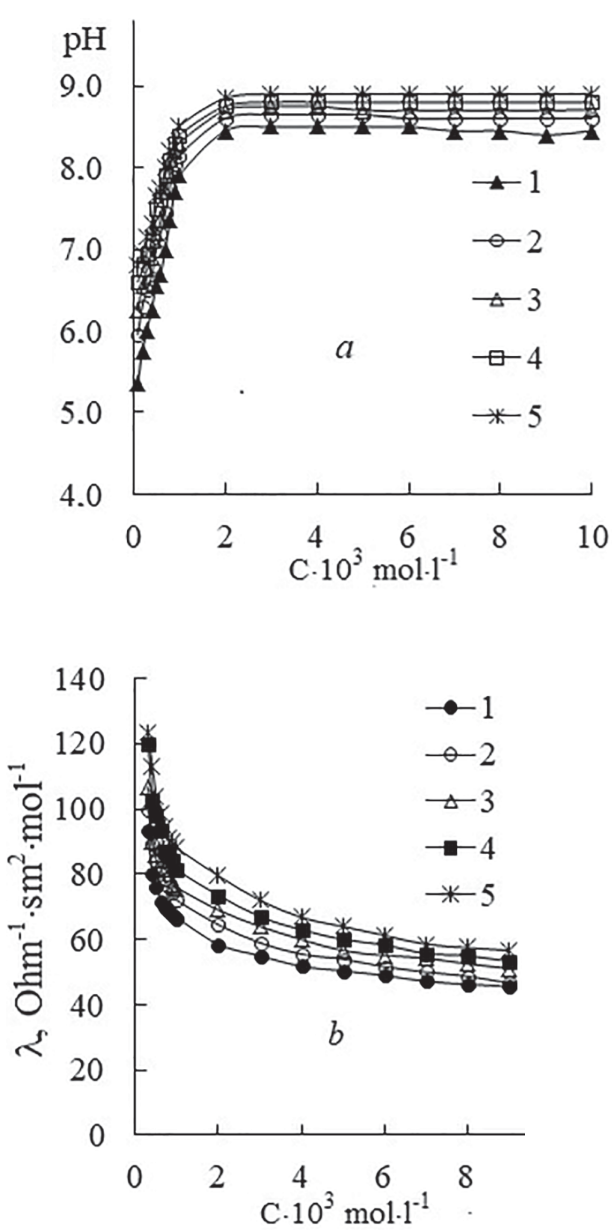

Fig. 5. $\mathrm{pH}(a)$ and molar conductivity $(b)$ of aqueous solutions of BzAMSNa. T (K): 293-1; $298-2 ; 303-3 ; 308-4 ; 313-5$. 
Along with this, dissociation (7) of $\mathrm{HSO}_{3}^{-}$ occurs, as well as protonation (8) and (9) at the nitrogen atoms of $\mathrm{N}$-alkylaminomethanesulfonate ions and alkyl-aminomethanol, respectively:

$$
\begin{gathered}
\mathrm{HSO}_{3}^{-} \underset{\leftarrow}{\longrightarrow} \mathrm{H}^{+}+\mathrm{SO}_{3}^{2-}, \\
\mathrm{YNHCH}_{2} \mathrm{SO}_{3}^{-}+\mathrm{H}^{+} \stackrel{\rightarrow}{\leftarrow} \stackrel{+}{\mathrm{N}} \mathrm{H}_{2} \mathrm{CH}_{2} \mathrm{SO}_{3}^{-}, \\
\mathrm{YNHCH}_{2} \mathrm{OH}+\mathrm{H}^{+} \stackrel{+}{\leftarrow} \mathrm{Y}^{+} \mathrm{HCH}_{2} \mathrm{OH} .
\end{gathered}
$$

In this case, the material balance according to YAMSNa takes the form (10), and the condition of electroneutrality - (11). In addition, equation (12) must be taken into account.

$$
\begin{gathered}
\mathrm{Q}_{\mathrm{YAMSA}}=\left[\mathrm{YNHCH}_{2} \mathrm{SO}_{3}^{-}\right]+ \\
+\left[\mathrm{YNHCH}_{2} \mathrm{OH}\right]+\left[\mathrm{Y}^{\mathrm{N}} \mathrm{H}_{2} \mathrm{CH}_{2} \mathrm{SO}_{3}^{-}\right]+ \\
+\left[\stackrel{+}{\mathrm{N}} \mathrm{HCH}_{2} \mathrm{OH}\right]
\end{gathered}
$$

$$
\begin{gathered}
{\left[\mathrm{YNHCH}_{2} \mathrm{SO}_{3}^{-}\right]+\left[\mathrm{OH}^{-}\right]+\left[\mathrm{HSO}_{3}^{-}\right]+} \\
+2\left[\mathrm{SO}_{3}^{2-}\right]=\left[\mathrm{H}^{+}\right]+\left[\mathrm{Na}^{+}\right]+\left[\mathrm{Y}^{+} \mathrm{HCH}_{2} \mathrm{OH}\right] \\
{\left[\mathrm{YNHCH}_{2} \mathrm{OH}\right]+\left[\mathrm{Y}^{+} \mathrm{HCH}_{2} \mathrm{OH}\right]=} \\
=\left[\mathrm{HSO}_{3}^{-}\right]+\left[\mathrm{SO}_{3}^{2-}\right]
\end{gathered}
$$

Due to the lack of data on equilibrium (9), we calculated, similarly to $[6,8]$, the ion-molecular composition of aqueous solutions of YAMSNa only at $\mathrm{pH}>7.0$ on the basis of pH-metric data (Fig. 1a-5a).

The ionic strength of sodium aminomethane sulfonate solutions at $\mathrm{pH}>7.0$ is determined by the following expression:

$$
\begin{aligned}
& \mu= \frac{1}{2} \cdot\left(\left[\mathrm{YNHCH}_{2} \mathrm{SO}_{3}^{-}\right] \cdot(-1)^{2}+\right. \\
&+\left[\mathrm{OH}^{-}\right] \cdot(-1)^{2}+\left[\mathrm{H}^{+}\right] \cdot(-1)^{2}+\left[\mathrm{Na}^{+}\right] \cdot(-1)^{2}+ \\
&\left.+\left[\mathrm{Y} \mathrm{N}_{2}^{+} \mathrm{CH}_{2} \mathrm{SO}_{3}^{-}\right] \cdot|2|^{2}\right)
\end{aligned}
$$

According to the definition [18], the coefficient $A_{i}$ in equation (15) is the negative decimal logarithm of the thermodynamic hydrolysis constant $K_{\mathrm{h}}$. The $\mathrm{p} K_{\mathrm{h}}=f(\mathrm{~T})$ dependences are shown in Fig. 6. $\mathrm{N}$-alkylaminomethanesulfonate anions by reaction (1) does not exceed $2.0 \%$, then $\mu$ is practically equal to $\mathrm{C}_{\mathrm{YAMSNa}}$ for all studied sodium aminomethanesulfonates in the region $\mathrm{C}_{\mathrm{YAMSNa}}=\left(2.0 \div 10 \cdot 10^{-3} \mathrm{~mol} \cdot \mathrm{l}^{-1}\right.$ in the investigated temperature range.

Using the obtained data, the constants of hydrolysis (2) of aminomethanesulfonate and $\mathrm{N}$-alkylaminomethanesulfonate anions were calculated.

$$
\mathrm{p} K_{\mathrm{h}}=-\lg K_{\mathrm{h}}
$$

by the equation (15), coefficients of which are in the Table 1.

$$
\mathrm{p} K_{\mathrm{h}}=A_{i}+B_{i} \cdot \sqrt{\mu}+\mathrm{C}_{i} \cdot \mu
$$

Analyzing the data in the table. 1, it should be noted that for the studied acids the constants of equation (15) are related to each other by directly proportional dependences (16) - (19).

$$
\begin{gathered}
B_{\mathrm{AMS}}=-731.2+157.6 \cdot A_{\mathrm{AMS}}- \\
-8.148 \cdot\left(A_{\mathrm{AMS}}\right)^{2} ; \mathrm{R}^{2}=0.9985 \\
C_{\mathrm{AMS}}=4902+1039 \cdot A_{\mathrm{AMS}}+ \\
+53.66 \cdot\left(A_{\mathrm{AMS}}\right)^{2} ; \mathrm{R}^{2}=0.9980 \\
B_{\mathrm{BzAMS}}=-165.3+45.31 \cdot A_{\mathrm{BzAMS}}- \\
-2.550 \cdot\left(A_{\mathrm{BzAMS}}\right)^{2} ; \mathrm{R}^{2}=0.9879 \\
C_{\mathrm{BzAMS}}=1129+292.5 \cdot A_{\mathrm{BzAMS}}+ \\
+16.60 \cdot\left(A_{\mathrm{BzAMS}}\right)^{2} ; \mathrm{R}^{2}=0.9846
\end{gathered}
$$

(1) 
The observed straight-line dependences (Fig. 7) of the thermodynamic constants of hydrolysis of N-methyl, N-tert-butyl and $\mathrm{N}$-benzyl-aminomethanesulfonate anions on the thermodynamic constants of hydrolysis of aminomethanesulfonate anions are described by the equation (20), the parameters of which are given in the Table 2 , and testify to the similarity in these processes.

$$
\begin{aligned}
& \mathrm{p} K_{\mathrm{h}}^{\mathrm{T}}\left(\mathrm{YNHCH}_{2} \mathrm{SO}_{3}^{-}\right)= \\
& =A_{i}+B_{i} \cdot \mathrm{p} K_{\mathrm{h}}^{\mathrm{T}}\left(\mathrm{NH}_{2} \mathrm{CH}_{2} \mathrm{SO}_{3}^{-}\right)
\end{aligned}
$$

Table 1

The values of the coefficients in equation (15) for aqueous solutions of YAMSNa.

\begin{tabular}{|c|c|c|c|c|}
\hline T, K & $A_{i}$ & $B_{i}$ & $C_{i}$ & $\mathrm{R}^{2}$ \\
\hline \multicolumn{5}{|c|}{$\mathrm{NH}_{2} \mathrm{CH}_{2} \mathrm{SO}_{3}^{-}$} \\
\hline 293 & 10.63 & 23.06 & -76.68 & 0.9999 \\
\hline 298 & 10.31 & 27.03 & -102.4 & 0.9997 \\
\hline 303 & 10.04 & 29.59 & -119.1 & 0.9992 \\
\hline 308 & 9.87 & 30.18 & -122.8 & 0.9991 \\
\hline 313 & 9.71 & 30.49 & -124.6 & 0.9991 \\
\hline \multicolumn{5}{|c|}{$\mathrm{H}_{3} \mathrm{CNHCH}_{2} \mathrm{SO}_{3}^{-}$} \\
\hline 298 & 10.72 & 16.66 & -39.07 & 0.9992 \\
\hline 303 & 10.52 & 17.35 & -42.37 & 0.9999 \\
\hline 308 & 10.27 & 19.63 & -56.03 & 0.9998 \\
\hline 313 & 10.15 & 19.10 & -52.63 & 0.9997 \\
\hline \multicolumn{5}{|c|}{$\mathrm{HOCH}_{2} \mathrm{CH}_{2} \mathrm{NHCH}_{2} \mathrm{SO}_{3}^{-}$} \\
\hline 293 & 10.74 & 20.05 & -57.10 & 0.9998 \\
\hline 298 & 10.40 & 24.28 & -83.49 & 0.9999 \\
\hline 303 & 10.20 & 24.97 & -87.45 & 0.9997 \\
\hline 308 & 10.38 & 17.04 & -40.03 & 0.9999 \\
\hline 313 & 10.14 & 19.16 & -51.87 & 0.9999 \\
\hline \multicolumn{5}{|c|}{$\left(\mathrm{CH}_{3}\right)_{3} \mathrm{CNHCH}_{2} \mathrm{SO}_{3}^{-}$} \\
\hline 298 & 10.19 & 29.48 & -116.9 & 0.9992 \\
\hline 303 & 10.15 & 26.04 & -94.36 & 0.9999 \\
\hline 308 & 9.91 & 28.34 & -109.6 & 0.9996 \\
\hline 313 & 9.75 & 28.63 & -111.5 & 0.9993 \\
\hline \multicolumn{5}{|c|}{$\mathrm{C}_{6} \mathrm{H}_{5} \mathrm{CH}_{2} \mathrm{NHCH}_{2} \mathrm{SO}_{3}^{-}$} \\
\hline 293 & 10.36 & 29.78 & -119.5 & 0.9994 \\
\hline 298 & 10.13 & 31.45 & -130.9 & 0.9995 \\
\hline 303 & 9.94 & 32.25 & -136.3 & 0.9995 \\
\hline 308 & 9.74 & 33.73 & -147.1 & 0.9992 \\
\hline 313 & 9.58 & 33.99 & -148.6 & 0.9991 \\
\hline
\end{tabular}

$$
\mathrm{C}_{\mathrm{YAMSNa}}=(0.1 \div 10.0) \cdot 10^{-3} \mathrm{~mol} \cdot \mathrm{l}^{-1} ; \mathbf{n}=9
$$


Thus, the molar electrical conductivity of aqueous solutions of sodium aminomethanesulfonates is determined by the equation (21):

$$
\begin{aligned}
\lambda & =\lambda_{\mathrm{Na}^{+}}^{0} \cdot a_{\mathrm{Na}^{+}}+\lambda_{\mathrm{OH}^{-}}^{0} \cdot a_{\mathrm{OH}^{-}}+ \\
& +\lambda_{\mathrm{YNHCH}_{2} \mathrm{SO}_{3}^{-}}^{0} \cdot a_{\mathrm{YNHCH}_{2} \mathrm{SO}_{3}^{+}}+ \\
& +\lambda_{\mathrm{YNH}_{2} \mathrm{CH}_{2} \mathrm{SO}_{3}^{-}}^{0} \cdot a_{\mathrm{YNH}_{2} \mathrm{CH}_{2} \mathrm{SO}_{3}^{-}} .
\end{aligned}
$$

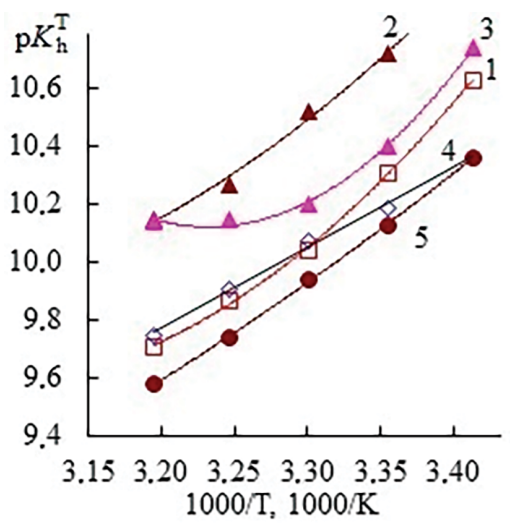

Fig. 6. Temperature dependence of thermodynamic hydrolysis constants of $\mathrm{YNHCH}_{2} \mathrm{SO}_{3}^{-}$.

$$
\mathrm{Y}-\mathrm{H}(1), \mathrm{CH}_{3}(2), \mathrm{HOCH}_{2} \mathrm{CH}_{2}(3)
$$

Table 2

Coefficient values in the equation (20)

\begin{tabular}{c|c|c|c}
\hline \hline $\mathrm{Y}$ & $A_{i}$ & $B_{i}$ & $\mathrm{R}^{2}$ \\
\hline $\mathrm{CH}_{3}$ & 0.5854 & 0.9847 & 0.9804 \\
$\left(\mathrm{CH}_{3}\right)_{3} \mathrm{C}$ & 2.6621 & 0.7332 & 0.9571 \\
$\mathrm{C}_{6} \mathrm{H}_{5} \mathrm{CH}_{2}$ & 1.4430 & 0.8413 & 0.9883 \\
\hline \hline
\end{tabular}

$R$-squared values $\left(R^{2} \geq 0.98\right)$ indicate a satisfactory nature of the correlation according to equation (22), and the values of the limiting electrical conductivity $\left(\lambda_{0}\right)$ are numerically equal to the coefficients $B_{0}$. Thus, the experimental values of the limiting molar electrical
Data on the electrical conductivity of aqueous solutions of sodium aminomethanesulfonates given in the Table 3 , represent the result of a correlation analysis of the dependence of $\lambda$ $\left(\mathrm{Ohm}^{-1} \cdot \mathrm{sm}^{2} \cdot \mathrm{mol}^{-1}\right)$ on the molar concentration of YAMSNa in a four-parameter dependence according to Shidlovsky (22), which describes the behavior of solutions of weak 1:1 electrolytes at a concentrations more than $10^{-3} \mathrm{~mol} \cdot \mathrm{l}^{-1}[19]$.

$$
\lambda=B_{0}+B_{1} \cdot \mathrm{C}^{0.5}+B_{2} \cdot \mathrm{C}+B_{3} \cdot \mathrm{C}^{1.5}
$$

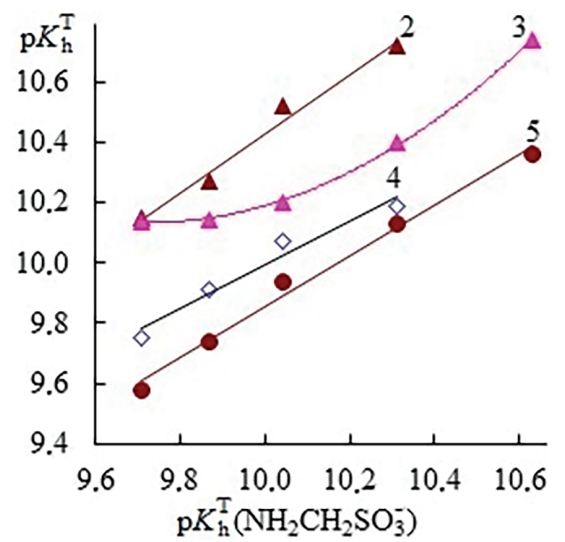

Fig. 7. Mutual dependences of thermodynamic hydrolysis constants of $\mathrm{YNHCH}_{2} \mathrm{SO}_{3}^{-}$.

(3), $\left(\mathrm{CH}_{3}\right)_{3} \mathrm{C}(4)$ and $\mathrm{C}_{6} \mathrm{H}_{5} \mathrm{CH}_{2}$ (5).

conductivity of aqueous solutions of sodium aminomethanesulfonates obtained by extrapolation according to Shidlovsky, like $\lambda_{0}$ of aqueous solutions of $\mathrm{N}$-derivatives of amino-methanesulfonic acid [16], increase with increasing temperature.

According to Kohlrausch's law for weak electrolytes [20], the limiting electrical conductivity of aqueous solutions of sodium aminomethanesulfonates is determined by expression (23).

$$
\begin{aligned}
& \lambda_{\mathrm{YNHCH}_{2} \mathrm{SO}_{3} \mathrm{Na}}^{0}=\lambda_{\mathrm{Na}^{+}}^{0}+h^{0}\left(\lambda_{\mathrm{OH}^{-}}^{0}+\right. \\
+ & \left.\lambda_{\mathrm{YNH}_{2} \mathrm{CH}_{2} \mathrm{SO}_{3}^{+}}^{0}\right)+\left(1-h^{0}\right) \lambda_{\mathrm{YNHCH}_{2} \mathrm{SO}_{3}^{-}}^{0},
\end{aligned}
$$


where $h^{0}$ - the degree of hydrolysis of aminomethanesulfonate ions at infinite dilution.

In infinitely dilute solutions of hydrolyzed $\mathrm{YNHCH}_{2} \mathrm{SO}_{3} \mathrm{Na}$, hydrolysis occurs at the anion (1). The degree of hydrolysis will be determined, like [20], by the following equation:

$$
h^{0}=\frac{\sqrt{K_{\mathrm{w}}}}{K_{\mathrm{h}}^{\mathrm{T}}+\sqrt{K_{\mathrm{w}}}} .
$$

Then the limiting molar electrical conductivity of sodium aminomethanesulfonates is:

$$
\begin{gathered}
\lambda_{\mathrm{YNHCH}_{2} \mathrm{SO}_{3} \mathrm{Na}}^{0}=\lambda_{\mathrm{Na}^{+}}^{0}+\frac{\sqrt{K_{\mathrm{w}}}}{K_{\mathrm{h}}^{\mathrm{T}}+\sqrt{K_{\mathrm{w}}}}\left(\lambda_{\mathrm{OH}^{-}}^{0}+\right. \\
\left.+\lambda_{\mathrm{YNH}_{2}^{+} \mathrm{CH}_{2} \mathrm{SO}_{3}}^{0}\right)+ \\
+\left(1-\frac{\sqrt{K_{\mathrm{w}}}}{K_{\mathrm{h}}^{\mathrm{T}}+\sqrt{K_{\mathrm{w}}}}\right) \lambda_{\mathrm{YNHCH}_{2} \mathrm{SO}_{3}^{-}}^{0}
\end{gathered}
$$

\begin{tabular}{|c|c|c|c|c|c|}
\hline $\mathrm{T}, \mathrm{K}$ & $B_{0}$ & $-B_{1}$ & $B_{2} \cdot 10^{-5}$ & $-B_{3} \cdot 10^{-5}$ & $\mathrm{R}^{2}$ \\
\hline \multicolumn{6}{|c|}{ AMSNa } \\
\hline 293 & 1364 & 54663 & 7.8136 & 40.00 & 0.9789 \\
\hline 298 & 1384 & 54526 & 7.7048 & 40.00 & 0.9814 \\
\hline 303 & 1447 & 56444 & 7.9312 & 40.00 & 0.9841 \\
\hline 308 & 1546 & 60086 & 8.4271 & 40.00 & 0.9841 \\
\hline 313 & 1759 & 70660 & 100.00 & 50.00 & 0.9805 \\
\hline \multicolumn{6}{|c|}{ MeAMSNa } \\
\hline 298 & 131.5 & 1757 & 0.2402 & 1.160 & 0.9783 \\
\hline 303 & 174.7 & 2021 & 0.1345 & 0.160 & 0.9912 \\
\hline 308 & 296.5 & 8141 & 1.1200 & 5.110 & 0.9965 \\
\hline 313 & 295.4 & 7788 & 1.0800 & 5.010 & 0.9936 \\
\hline \multicolumn{6}{|c|}{ HEAMSNa } \\
\hline 293 & 183.5 & 2524 & 0.0826 & 0.517 & 0.9802 \\
\hline 298 & 235.0 & 4356 & 0.3286 & 0.606 & 0.9874 \\
\hline 303 & 242.5 & 4991 & 0.2946 & 0.445 & 0.9879 \\
\hline 308 & 264.2 & 4595 & 0.4183 & 1.440 & 0.994 \\
\hline 313 & 309.4 & 5860 & 0.5500 & 1.730 & 0.9937 \\
\hline \multicolumn{6}{|c|}{$t$-BuAMSNa } \\
\hline 298 & 105.5 & 1410 & 0.0200 & 1.000 & 0.9393 \\
\hline 303 & 136.4 & 2602 & 0.3833 & 1.890 & 0.9798 \\
\hline 308 & 171.9 & 3859 & 0.5636 & 2.770 & 0.9940 \\
\hline 313 & 201.3 & 4456 & 0.5930 & 2.650 & 0.9740 \\
\hline \multicolumn{6}{|c|}{ BzAMSNa } \\
\hline 293 & 112.1 & 2192 & 0.2724 & 1.220 & 0.9947 \\
\hline 298 & 125.0 & 2443 & 0.2951 & 1.310 & 0.9951 \\
\hline 303 & 123.9 & 2232 & 0.2709 & 1.220 & 0.9918 \\
\hline 308 & 149.2 & 3154 & 0.3921 & 1.750 & 0.9907 \\
\hline 313 & 147.3 & 2696 & 0.0309 & 1.330 & 0.9910 \\
\hline
\end{tabular}

Table 3

Parameters of Shidlovsky equation (22) for aqueous solutions YAMSNa. $\mathrm{C}_{\mathrm{YAMSNa}}=(1.0 \div 10.0) \cdot 10^{-3} \mathrm{~mol}^{-1} ; \mathbf{n}=15$ 
The observed linear dependences (Fig. 8) of the limiting molar electrical conductivity of aqueous solutions of N-methyl, N-2-hydroxyethyl, N-tert-butyl and N-benzyl-aminomethanesodium sulfonates on the limiting molar conductivity of aqueous solutions of sodium aminomethanesulfonate are described by equation (26), the parameters of which are given in the Table 4 , and testify to the similarity in these processes.

$$
\lambda_{\mathrm{YNH}_{2} \mathrm{CH}_{2} \mathrm{SO}_{3} \mathrm{Na}}^{0}=A_{i}+B_{i} \cdot \lambda_{\mathrm{NH}_{2} \mathrm{CH}_{2} \mathrm{SO}_{3} \mathrm{Na}}^{0}
$$

Judging by the data in the Table $3, \mathrm{~N}$-alkylation of sodium aminomethanesulfonate leads to a decrease in the values of the limiting molar electrical conductivity of its aqueous solutions. This fact is indicated by negative values of the coefficient $A_{i}$ in equation (26) (Table 4).

Considering the fact that the limiting mobility of hydroxide ions and $\mathrm{Na}^{+}$at $298 \mathrm{~K}$ are respectively equal to $199.2 \mathrm{Ohm}^{-1} \cdot \mathrm{sm}^{2} \cdot \mathrm{mol}^{-}$ ${ }^{1}$ and $50.1 \mathrm{Ohm}^{-1} \cdot \mathrm{sm}^{2} \cdot \mathrm{mol}^{-1}[21]$, then

$$
\begin{gathered}
\lambda^{0}(\mathrm{AMSNa})>\lambda^{0}(\mathrm{HEMSNa})>\lambda^{0}\left(\mathrm{OH}^{-}\right)> \\
>\lambda^{0}(\mathrm{MeAMSNa}) \approx \lambda^{0}\left(\mathrm{BzAMSNa}^{\circ}\right)> \\
>\lambda^{0}(t \mathrm{BuAMSNa})>\lambda^{0}\left(\mathrm{Na}^{+}\right) \text {and } \\
\lambda^{0}(\mathrm{AMSNa})>\lambda^{0}\left(\mathrm{OH}^{-}\right)+\lambda^{0}\left(\mathrm{Na}^{+}\right)> \\
>\lambda^{0}(\mathrm{HEMSNa})>\lambda^{0}(\mathrm{MeAMSNa}) \approx \\
\approx \lambda^{0}(\mathrm{BzAMSNa})>\lambda^{0}(\text { tBuAMSNa }) .
\end{gathered}
$$

The latter, obviously, indicates a decrease in the mobility of hydroxide ions in solutions of MeAMSNa, HEAMSNa, $t$-BuAMSNa, BzAM$\mathrm{SNa}$, compared with the value of mobility during the transfer along the chains of water H-bonds. A similar situation occurs with the mobility of hydroxonium ions in aqueous solutions of MeAMSA, HEAMSA, $t$-BuAMSNa [16] and aspartic acid [22], as well as with the mobility of hydroxyl ions in HEAMSA solutions [16].

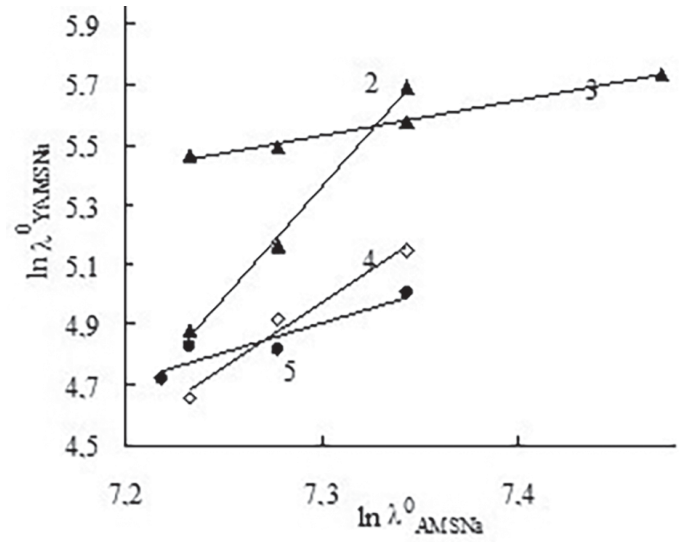

Fig. 8. Mutual dependences of the limiting molar electrical conductivity of aqueous solutions $\mathrm{YNHCH}_{2} \mathrm{SO}_{3} \mathrm{Na}$. Y $-\mathrm{CH}_{3}(2), \mathrm{HOCH}_{2} \mathrm{CH}_{2}$ (3), $\left(\mathrm{CH}_{3}\right)_{3} \mathrm{C}(4)$ and $\mathrm{C}_{6} \mathrm{H}_{5} \mathrm{CH}_{2}(5)$.

Table 4

Coefficient values in the equation (26)

\begin{tabular}{l|c|c|c}
\hline \multicolumn{1}{c|}{$\mathrm{Y}$} & $A_{i}$ & $B_{i}$ & $\mathrm{R}^{2}$ \\
\hline $\mathrm{CH}_{3}$ & -48.623 & 7.3949 & 0.9964 \\
$\mathrm{HOCH}_{2} \mathrm{CH}_{2}$ & -3.0572 & 1.1761 & 0.9948 \\
$\left(\mathrm{CH}_{3}\right)_{3} \mathrm{C}$ & -26.707 & 4.3399 & 0.9798 \\
$\mathrm{C}_{6} \mathrm{H}_{5} \mathrm{CH}_{2}$ & -9.4619 & 1.9683 & 0.8684 \\
\hline \hline
\end{tabular}

Activation parameters of electrical conductivity of aqueous solutions of sodium aminomethane sulfonates

The dependences of $\ln \lambda$ on $1 / \mathrm{T}$ are linear, which makes it possible to determine the effective activation energies of electrical conductivity [19] (Table 5). Transferring the analogy between the Arrhenius equations (27) and Eyring (28) from kinetics to electrical conductivity, we calculated the activation enthalpy of electrical conductivity using equation (29) and the activation entropy using equation (30) [19], the values of which are given in the Table 5 . 


$$
\begin{gathered}
\mathrm{k}=\mathrm{A} \cdot \mathrm{e}^{-\frac{\mathrm{E}_{\mathrm{a}}}{\mathrm{RT}}} \\
\lambda=\mathrm{A} \cdot \mathrm{e}^{-\frac{\mathrm{E}_{\mathrm{a}}}{\mathrm{RT}}} \\
\Delta \mathrm{H}^{\#}=\mathrm{E}_{\mathrm{a}}-\mathrm{RT} \\
\Delta \mathrm{S}^{\#}=-205.8+19.15 \cdot \lg \lambda / \mathrm{T}+\mathrm{E}_{\mathrm{a}} / \mathrm{T}
\end{gathered}
$$

The processes of formation of activated complexes $0.001 \leq \mathrm{Q}_{\mathrm{YAMSA}} \leq 0.009 \mathrm{M}$ are endothermic (Table 5). Negative values of $\Delta \mathrm{S}^{\#}$ indicate that atoms in activated complexes are located more "compactly" than in initial systems [23], that is, during the formation of activated complexes, the number of rotational and vibrational degrees of freedom decreases. For the reactions of association and dimerization, the activation entropies have large numerical values [24]. The same is observed for the molar electrical conductivity of aqueous solutions of $\mathrm{N}$-alkylaminomethanesulfonic acids [16].

The entropic and enthalpy components of the studied processes mutually compensate each other (Table 5). The compensatory effect is expressed by equation (31), the parameters of which are given in the Table 6, which corresponds to the presence of a compensation effect similar to the usual kinetic effect with the temperature $\mathrm{T}_{\mathrm{i} \lambda}$ similar to the isokinetic one.

$$
\Delta H^{\#}=\alpha_{i}+\mathrm{T}_{\mathrm{i} \lambda} \cdot \Delta S^{\#}
$$

In the case of the parameters of equation (30), a compensation effect is also observed [25] (Table 5), expressed by equation (32), the parameters of which are given in the Table 7.

$$
\ln (\mathrm{A})=\alpha_{i}+\mathrm{E}_{\mathrm{a}} /\left(\mathrm{R} \cdot \mathrm{T}_{\mathrm{i} \lambda}\right)
$$

Table 5

\section{Activation parameters of electrical conductivity of YAMSNa water solutions according to Eyring. $T=298 \mathrm{~K}$}

\begin{tabular}{c|c|c|c|c|c}
\hline \hline $\mathrm{C}_{\text {YAMSNa }} \cdot 10^{-3}, \mathrm{M}$ & $\mathrm{E}_{\mathrm{a}}, \mathrm{kJ} \cdot \mathrm{mol}^{-1}$ & $\ln (\mathrm{A})$ & $\mathrm{R}^{2}$ & $\Delta \mathrm{H}^{\#}, \mathrm{~kJ} \cdot \mathrm{mol}^{-1}$ & $\Delta \mathrm{S}^{\#}, \mathrm{~J}^{2} \mathrm{~mol}^{-1} \cdot \mathrm{K}^{-1}$ \\
\hline \multicolumn{5}{c}{ AMSNa } \\
\hline 0.5 & 10.6 & 10.52 & 0.9647 & 8.14 & -170 \\
0.6 & 9.82 & 10.05 & 0.9918 & 7.34 & -173 \\
0.7 & 9.60 & 9.84 & 0.9939 & 7.13 & -173 \\
0.8 & 9.73 & 9.78 & 0.9760 & 7.26 & -173 \\
0.9 & 9.89 & 9.77 & 0.9996 & 7.41 & -172 \\
1.0 & 9.14 & 9.58 & 0.9954 & 6.67 & -175 \\
2.0 & 10.9 & 9.56 & 0.9701 & 8.43 & -169 \\
3.0 & 11.0 & 9.36 & 0.9846 & 8.54 & -169 \\
4.0 & 10.2 & 8.87 & 0.998 & 7.74 & -171 \\
5.0 & 10.5 & 8.87 & 0.9919 & 8.03 & -170 \\
6.0 & 10.6 & 8.83 & 0.9929 & 8.09 & -170 \\
7.0 & 10.0 & 8.53 & 0.9897 & 7.51 & -172 \\
8.0 & 9.67 & 8.34 & 0.9939 & 7.19 & -173 \\
9.0 & 10.0 & 8.43 & 0.9279 & 7.55 & -172 \\
\hline
\end{tabular}


Table 5 continuation

\begin{tabular}{|c|c|c|c|c|c|}
\hline \multicolumn{6}{|c|}{ MeAMSNa } \\
\hline 2.0 & 13.2 & 9.85 & 0.9973 & 10.7 & -161 \\
\hline 3.0 & 10.3 & 8.67 & 0.9990 & 7.85 & -171 \\
\hline 4.0 & 12.1 & 9.34 & 0.9996 & 9.66 & -165 \\
\hline 5.0 & 12.7 & 9.59 & 0.9919 & 10.2 & -163 \\
\hline 6.0 & 12.4 & 9.44 & 0.9975 & 9.88 & -164 \\
\hline 7.0 & 11.7 & 8.53 & 0.9897 & 9.23 & -166 \\
\hline 8.0 & 12.5 & 9.45 & 0.9995 & 10.0 & -164 \\
\hline 9.0 & 11.3 & 8.96 & 0.9916 & 8.78 & -168 \\
\hline \multicolumn{6}{|c|}{ HEAMSNa } \\
\hline 1.0 & 13.8 & 10.5 & 0.9947 & 11.4 & -159 \\
\hline 2.0 & 19.9 & 12.6 & 0.9702 & 17.4 & -139 \\
\hline 3.0 & 20.1 & 12.6 & 0.9502 & 17.6 & -138 \\
\hline 4.0 & 21.6 & 13.1 & 0.9617 & 19.2 & -133 \\
\hline 5.0 & 20.0 & 12.4 & 0.9513 & 17.5 & -139 \\
\hline 6.0 & 23.1 & 13.6 & 0.9534 & 20.6 & -128 \\
\hline 7.0 & 17.8 & 11.4 & 0.9365 & 15.3 & -146 \\
\hline 8.0 & 20.0 & 12.3 & 0.9528 & 17.5 & -139 \\
\hline 9.0 & 21.6 & 12.9 & 0.9325 & 19.1 & -133 \\
\hline \multicolumn{6}{|c|}{$t$-BuAMSNa } \\
\hline 1.0 & 17.2 & 11.3 & 0.9716 & 14.8 & -148 \\
\hline 2.0 & 12.1 & 9.21 & 0.9904 & 9.66 & -165 \\
\hline 3.0 & 20.1 & 12.6 & 0.9502 & 9.69 & -165 \\
\hline 4.0 & 12.3 & 9.24 & 0.9933 & 9.84 & -164 \\
\hline 5.0 & 12.9 & 9.44 & 0.9973 & 10.4 & -163 \\
\hline 6.0 & 12.7 & 9.36 & 0.9934 & 10.2 & -163 \\
\hline 7.0 & 13.0 & 9.50 & 0.9974 & 10.6 & -162 \\
\hline 8.0 & 12.8 & 9.39 & 0.9815 & 10.4 & -163 \\
\hline 9.0 & 12.9 & 9.40 & 0.9691 & 10.4 & -162 \\
\hline \multicolumn{6}{|c|}{ BzAMSNa } \\
\hline 1.0 & 10.2 & 8.36 & 0.9894 & 7.73 & -171 \\
\hline 2.0 & 11.4 & 8.74 & 0.9955 & 8.88 & -168 \\
\hline 4.0 & 9.71 & 7.94 & 0.9954 & 7.23 & -173 \\
\hline 5.0 & 8.90 & 7.58 & 0.9876 & 6.43 & -176 \\
\hline 6.0 & 9.68 & 7.86 & 0.9826 & 7.20 & -173 \\
\hline 7.0 & 8.29 & 7.26 & 0.9790 & 5.81 & -178 \\
\hline 8.0 & 8.49 & 7.32 & 0.9934 & 6.01 & -177 \\
\hline 9.0 & 8.68 & 7.37 & 0.9755 & 6.21 & -177 \\
\hline
\end{tabular}


Table 6

Values of parameters of equation (31) and physicochemical properties of sodium aminomethanesulfonates

\begin{tabular}{c|c|c|c|c|c|c}
\hline \hline Acid & $\alpha_{i}, \mathrm{~kJ} \cdot \mathrm{mol}^{-1}$ & $\mathrm{~T}_{\mathrm{i} \lambda}$ & $\mathrm{R}^{2}$ & $M R, \AA[7]$ & $\lg P_{\text {ow }}[7]$ & $V, \AA^{3}[7]$ \\
\hline MeMSNa & 58.81 & 298.0 & 0.999 & 24.15 & -0.27 & $506.8(3)$ \\
HEAMSNa & 58.85 & 298.0 & 0.999 & 30.44 & -0.71 & $637.32(8)$ \\
$\boldsymbol{t}$-BuAMSNa & 58.81 & 298.0 & 0.999 & 37.95 & 0.57 & $825.9(5)$ \\
BzAMSNa & 58.88 & 298.0 & 0.999 & 48.76 & 1.51 & $946.93(17)$ \\
\hline \hline
\end{tabular}

Keys: $\mathrm{R}^{2}$ - approximation confidence value; $M R$ - molar refractionя; $P_{\text {ow }}$ - partition coefficient in the octanol - water system; $V$ - molar volume.

Table 7

Values of parameters of equation (32)

\begin{tabular}{c|c|c|c}
\hline \hline Salt & $\alpha_{i}, \mathrm{~kJ} \cdot \mathrm{mol}^{-1}$ & $\mathrm{~T}_{\mathrm{i} \lambda}$ & $\mathrm{R}^{2}$ \\
\hline MeAMSNa & -1.444 & 310.9 & 0.999 \\
HEAMSNa & -1.860 & 343.0 & 0.974 \\
$t$-BuAMSNa & -1.177 & 288.4 & 0.999 \\
BzAMSNa & -0.750 & 242.2 & 0.998 \\
\hline \hline
\end{tabular}

Thus, by processing the data of conductometric studies, the activation parameters of the electrical conductivity of the systems "sodium aminomethanesulfonate - water" at 293-313 K were obtained. The obtained data on the acid-base and electrochemical properties of the YAMSNa $-\mathrm{H}_{2} \mathrm{O}$ systems are recommended for use in chemical analysis, microbiological and biochemical studies, as well as in the simulation of chemisorption processes of capturing acid gases $\left(\mathrm{CO}_{2}\right.$ and $\left.\mathrm{SO}_{2}\right)$.

Acknowledgement. The work was carried out with financial support from the Ministry of Education and Science of Ukraine.
ЕЛЕКТРОХІМІЧНІ ВЛАСТИВОСТІ ВОДНИХ РОЗЧИНІВ АМІНОМЕТАНСУЛЬФОНАТІВ HATPIЮ

P. Є. Хома ${ }^{1,2^{*}}$, А. А.-А. Еннан О. М. Чеботарвов², С. В. Водзінський, P. М. Длубовський ${ }^{1}$ С. В. Топоров ${ }^{2}$

${ }^{1}$ Фізико-хімічний інститут захисту навкотишнього середовища і людини, вул. Преображенська, 3, Одеса 65082;

${ }^{2}$ Одеський національний університет імені I. I. Мечникова, вул. Дворянська, 2, Одеса 65082

*e-mail: rek@onu.edu.ua

Здійснено $\mathrm{pH}$ - і кондуктометричне дослідження електрохімічних властивостей водних розчинів $\left(1 \cdot 10^{-4} \div 9 \cdot 10^{-3} \mathrm{M}\right)$ $\mathrm{YNHCH}_{2} \mathrm{SO}_{3} \mathrm{Na} \quad\left(\mathrm{Y}=\mathrm{H}(\mathrm{AMSNa}), \mathrm{CH}_{3}\right.$ (MeAMSNa), $\mathrm{HOCH}_{2} \mathrm{CH}_{2}$ (HEAMSNa), $\left(\mathrm{CH}_{3}\right)_{3} \mathrm{C}$ (t-BuAMSNa) и $\mathrm{C}_{6} \mathrm{H}_{5} \mathrm{CH}_{2}$ (BzAMSNa)) в області температур 293313 К. За результатами кондуктометричного дослідження систем $\mathrm{YNHCH}_{2} \mathrm{SO}_{3} \mathrm{Na}-$ $\mathrm{H}_{2} \mathrm{O}$ збільшення температури від 293 до 
313 К супроводжується підвищенням молярної електропровідності систем внаслідок зростання ступеня дисоціації електролітів i/або рухливості утворених іонів. При цьому для всіх досліджуваних систем кислотні властивості з ростом температури від 293 до 308 К знижуються. Оцінено концентраційні та температурні залежності констант гідролізу амінометансульфонату та $\mathrm{N}$-алкіламінометансульфонатів (алкіл: метил, 2-гідроксиетил, трет-бутил і бензил). Спостережувані прямолінійні залежності термодинамічних констант гідролізу $\mathrm{N}$-метил, $\mathrm{N}$-трет-бутил i N-бензил-амінометансульфонат аніонів від термодинамічних констант гідролізу амінометансульфонат аніонів свідчать про подібність в зазначених процесах. Розраховано значення граничної молярної електропровідності шляхом екстраполяції за Шидловським. 3 урахуванням літературних даних встановлено, що граничні рухливості зменшуються в рядах: $\lambda^{0}(\mathrm{AMSNa})>$ $\lambda^{0}(\mathrm{HEMSNa})>\lambda^{0}\left(\mathrm{OH}^{-}\right)>\lambda^{0}(\mathrm{MeAMSNa}) \approx$ $\lambda^{0}(\mathrm{BzAMSNa})>\lambda^{0}(t \mathrm{BuAMSNa})>\lambda^{0}\left(\mathrm{Na}^{+}\right)$ та $\lambda^{0}(\mathrm{AMSNa})>\lambda^{0}\left(\mathrm{OH}^{-}\right)+\lambda^{0}\left(\mathrm{Na}^{+}\right)>$ $\lambda^{0}(\mathrm{HEMSNa})>\lambda^{0}(\mathrm{MeAMSNa}) \approx \lambda^{0}(\mathrm{BzAMSNa})$ $>\lambda^{0}(t$-BuAMSNa $)$. Відзначено відносне зниження рухливості іонів водню в розчинах MeAMSNa, HEMS, $t$-BuAMSNa тa BzAMSNa порівняно 3 величиною рухливості при перенесенні по ланцюгах Н-зв'язків води. Виявлено компенсаційні ефекти в активаційних параметрах молярної електропровідності системи амінометансульфонат натрію - вода в області температур 293-313 К.

Ключові слова: амінометансульфокислоти, водні розчини, гідроліз, електропровідність.

\section{REFERENCES}

1. Grygorenko O.O., Biitseva A.V., Zhersh S. Amino sulfonic acids, peptidosulfonamides and other related compounds. Tetrahedron. 2018. 74(13): 1355. DOI: 10.1016/j. tet.2018.01.033

2. Ferreira C.M.H., Pinto I.S.S., Soares E.V., Soares H.M.V.M. (Un)suitability of the use of $\mathrm{pH}$ buffers in biological, biochemical and environmental studies and their interaction with metal ions - a review. RSC Adv. 2015. 5(39): 30989. DOI: 10.1039/c4ra15453c

3. Khoma R.E., Ennan A.A., Gridina T.L., Fedchuk A.S., Lozitskiy V.P., Rakipov I.M., Vladika A.S. Synthesis, Antioxidant and AntiInfluenza Activityof Aminomethanesulphonic Acids. Khimiko-Farmatsevticheskii Zhurn. 2019. 53(5): 28. DOI: 10.30906/0023-11342019-53-5-28-31 [in Russian].

4. Hrydina T.L., Khoma R.E., Ennan A.A.-A., Fedchuk A.S., Hruzevskyi O.A. Investigations of the antimicrobial activity of aminomethanesulfonic acids against strains of Staphylococcus aureus with different antimicrobial susceptibility. Zaporozhye Med. J. 2019. 21(2): 234. [in Ukrainian].

5. Khoma R.E., Baumer V.N., Antonenko P.B., Snihach A.O., Godovan V.V., Ennan A.A., Dlubovskii R.M., Gelmboldt V.V. Synthesis, crystal structure, and spectral characteristics of $\mathrm{N}$-(n-propyl)aminomethanesulfonic acid. Acute toxicity of aminomethanesulfonic acid and its $\mathrm{N}$-alkylated derivatives. Voprosy Khimii i Khimicheskoi Tekhnologii. 2019. (6): 255.

6. Khoma R.E., Osadchiy L.T., R. M. Dlubovskiy Aminomethanesulphonic acids and its $\mathrm{N}$-derivatives are components of N. Goods buffers. Visn. Odes. nac. univ. Him. 2015. 20(3): 66. DOI: 10.18524/23040947.2015.3(55).54005 [in Russian].

7. Khoma R.E. Thermodynamics of the dissociation of aminomethanesulfonic acid and its $\mathrm{N}$-substituent derivatives at 293-313 K. Russ. 
J. Phys. Chem. 2017. 91(1): 76. DOI: 10.1134/ S0036024417010125

8. Khoma R.E., Chebotaryov A.N., Osadchiy L.T., Vodzinskiy S.V., Toporov S.V. Acidbase properties of aminomethanesulphonic acid N-n-propyl, N-n-butyl and N-nheptyl derivatives. Visn. Odes. nac. univ. Him. 2019. 24(1): 12 DOI: $10.18524 / 2304-$ 0947.2019.1(69).158502 [in Russian].

9. Khoma R.E.., Ennan A.A.-A., Chebotaryov A.N., Vodzinskii S.V. Aminomethansulfonic and alkylaminomethansulfonic buffer systems. Ukr. Chem. J. 2019. (85)9: 3. DOI: 10.33609/0041-6045.85.9.2019.3-16 [in Russian].

10.Witt A.C., Lakshminarasimhan M., Remington B.C., Hasim S., Pozharski E., Wilson M.A. Cysteine $\mathrm{pK}_{\mathrm{a}}$ Depression by a Protonated Glutamic Acid in Human DJ-1. Biochem. 2008. 47(28): 7430. DOI: 10.1021/bi800282d

11.Pattnaik S., Dash U.N. Studies on Ion Association and Solvent InteractionConductance of Glycine in Aqueous Solutions of Hydrotropic Agents at Different Temperatures. Chem. Sci. Trans. 2013. 2(4): 1503. DOI: $10.7598 /$ cst2013.572

12.Dhapte V., Mehta P. Advances in hydrotropic solutions: An updated review. St. Petersburg Polytech. University J.: Phys. Math. 2015. 1(4): 424. DOI: 10.1016/j.spjpm.2015.12.006

13.Pattnaik S., Dash U.N. Influence of hydrotropic agents on the solute - solvent interactions in aqueous solutions of glycine at different temperatures. J. Chem. Pharm. Res. 2012. 4(9): 4364.

14. Khoma R.E., Shestaka A.A., Shishkin O.V., Baumer V.N., Brusilovskii Yu.E., Koroeva L.V., Ennan A.A., Gel'mbol'dt V.O. Features of interaction in the sulfur(IV) oxide-hexamethylenetetramine-water system: A first example of identification of the product with a sulfur-carbon bond. Russ. J. Gen. Chem. 2011. 81(3): 620. DOI: $10.1134 / S 1070363211030352$

15. Khoma R.E. Electrochemical Properties of Aminomethanesulphonic Acid - Water System. Visn. Odes. nac. univ. Him. 2013. 18(3): 89. DOI: 10.18524/2304-0947.2013. 3(47).31179 [in Russian].

16.Khoma R.E., Chebotaryov A.N., Kalarash K.N., Osadchiy L.T. Conductivity of aminomethanesulphonic acids $\mathrm{N}$-derivatives aqueous solutions. Visn. Odes. nac. univ. Him. 2018. 23(3): 16. DOI: 10.18524/23040947.2018.3(67).140798 [in Russian].

17.McMillan F.H., Pattison I.C. Sodium Colistimethate I: Dissociations of Aminomethanesulfonates in Aqueous Solution. J. Pharm. Sci. 1969. 58(6): 730. DOI: $10.1002 /$ jps.2600580618

18. Hartley F.R., Burgess C. Alcock R.M. Solution Equilibria. (Ellis Horwood Limited:. Chichester, West Sussex, England, 1980).

19.Krestov G.A., Novoselov N.P., Perelygin I.S., Kolker A.M., Safonova L.P., Ovchinnikova V.D., Trostin V.N. Ion solvatation. (Moscow: Nauka, 1987). [in Russian]

20.Stetsyk V.V. The refinement of limiting molar conductivities of weak acids and bases. Kharkov University Bulletin. Chemical Series. 2013. (22): 150. [in Russian]

21.Goronovsky I.T., Nazarenko Yu.P., Nekryach E.F. Quick reference book on chemistry. (Kiyv: Naukova dumka, 1987), 73. [in Russian] 22.Strelnikova O.U., Aristov I.V., Bobreshova O.V., Kulintsov P.I., Stepanenko L.V. Electrotransport in aqueous solutions of amino acids. Process. VSU. Series: Chemistry, Biology. 2001. (1): 182. [in Russian]

23. Daniels F., Alberty R. Physical chemistry. (Moscow: Mir, 1978). [in Russian]

24.Zaitsev O.S. General chemistry. State of substances and chemical reactions. (Moscow: Chemistry, 1990), 597. [in Russian]

25. Budanov V.V. Compensation effect in chemical reaction kinetics and possibility of determination of its existens. Izvestiya VUZ. Khimiya i Khimicheskaya Tekhnologiya. 2009. 52(8): 23. [in Russian]

Стаття надійшла 26.11.2020. 